\title{
POTENTIALS OF ELECTRONIC BUSINESS DEVELOPMENT IN SERBIA
}

\author{
Slavoljub Milovanovic
}

\begin{abstract}
Summary
Intensive application of information and communication technology (ICT), particularly Internet in selling and buying business processes have caused development of electronic business (e-business) concept. Numerous organizations in the world and in Serbia as well have implemented the concept. The basic aim of the paper is to analyse level of internet technology and e-business implementation in Serbia. The paper has theoretical background explaining concept of e-business and ICT which supports the implementation of this concept. However, empirical or practical contribution of the paper is articulated through analysis of data considering application of ICT and e-business concept in Serbia. The data considering application of ICT and e-business concept in Serbia is collected by Statistical Office of the Republic of Serbia and encompasses households/individuals and enterprises in Serbia. Results of the research presented in the paper can help executives in Serbian organizations in planning e-business concept implementation as well as researchers in deeper study of this theme.
\end{abstract}

Key words: Electronic business, electronic commerce, Internet, Serbia

JEL: $M 15, Q 13$

\section{Introduction}

The great number of people in the world use Internet for various purposes particularly for buying products and services. Also, numerous organizations in the world and in Serbia as well have implemented concept of electronic business (e-business) that supports online buying and selling. The basic aim of the paper is to analyse level of internet technology and e-business implementation and potentials in Serbia.

There are many theoretical researches in Serbia that deals with analysis of e-business concept, information and communication technology (ICT) application in e-business, advantages of this concept and challenges in its implementation (Ivkovic, Radenkovic, 1998), (Jovanovic, Milovanovic, 2010), (Koncar, 2003), (Radenkovic, 2007). Empirical researches are very rare and this paper tries to study and analyse this theme

1 Slavoljub Milovanovic Ph.D., Full Professor, University of Nis, The Faculty of Economics in Nis, Trg Kralja Aleksandra 11, 18000 Nis, Phone: +381 18528 644, E-mail: smilovan@eknfak.ni.ac.rs 
from empirical and practical view. Intent of author of this paper is to present results of the research to academic and business community in Serbia and the other countries. Results of this research can be used by managers in enterprises, researchers in academic institutions and policy makers on national and local level.

In addition, the research has theoretical background explaining concept of e-business and ICT which supports the concept. Theoretical themes briefly explained after the section of methodology are: forms and models of e-business, internet technologies supporting e-business and e-business integration solutions.

\section{Methodology and data sources}

Empirical contribution of the paper is articulated through analysis of data considering application of Internet and e-business in Serbia. Data for this research is collected by Statistical Office of the Republic of Serbia. Therefore, author of the paper is not engaged in collection of the data but only uses it for analysis and making conclusions.

The investigation of the Statistical Office (SORS, 2014) about use of Internet in Serbia includes households (individuals) and enterprises. The investigation is made by interview method on the sample of 2400 households and 1400 enterprises. The research is conducted in 2014 year, but collected data is related to 2013 year.

Research of households and individuals made by telephone interview is conducted from 17. to 31. march in 2014. Target population for households is all households with at least one member with age between 16 and 74. Type of this sample is twophased and stratified. Scope of this research is territory of Republic of Serbia without the Autonomous Province of Kosovo. Individuals are divided by gender, level of education, level of households' income and employment or unemployment status.

On the other side, the research of enterprises made by telephone interview is conducted from 17. to 30. April in 2014. Target sample was 1200 enterprises with 10 and more employees and this sample is stratified and representative encompassing territory of Republic of Serbia without the Autonomous Province of Kosovo.

\section{Theoretical background}

As that is previously mentioned, theoretical themes briefly explained in the next few sections are related to forms and models of e-business (for example, wired and mobile e-business, Business-to-Consumer and Business-to-Business model of e-commerce, etc.), internet technologies supporting e-business (broadband networks, web, intranet, extranet etc.) and e-business integration solutions (Supply Chain Management, Customer Relationship Management and Enterprise Resources Planning).

\section{Forms and models of e-business}

A common definition of e-business and e-commerce is difficult to give because of many different and inconsistent approaches. Depending on these approaches electronic 
business has different definitions, particularly with regard to communications, business process, service and online necessity. Many definitions do not strictly separate e-commerce and e-business. However, the definition of e-business is more complex and in this paper, e-business is viewed as a superset of e-commerce. E-business are those business activities that are a part of a value network; address the customer process; and use information and communication technologies (ICT) in an integrative way based on the organizational and cultural rules of the networked economy. On the other hand, e-commerce is narrower concept than e-business that encompasses buying and selling over digital media, so that e-commerce is the trade (sales, commerce, distribution) of goods and services by electronic means (Yoo et al., 2011).

Most definitions assume that e-business is enabled by the development and implementation of electronic media such as the Internet. Internet is viewed as a global computer network that enables communication and e-business transactions on global basis. In this paper, we accepted definition of e-commerce as doing business electronically, particularly via Internet that enables a dynamic set of technologies, applications and business processes that link enterprises, consumers and communities.

E-business has many forms. Traditional form of e-business is conducted through wired communication media while mobile form of e-business (mobile business or m-business) is enabled by wireless media and networks. Wireless and mobile technologies enable users of mobile devices (mobile phones, smartphones, tablets etc.) to use many information and services. Also, these technologies create a base for wireless local area networks (WLAN) which companies may use for supporting internal business processes.

Regardless of communication medium and technology through which business is doing, there are following basic e-business models: business-to-consumer (B2C) and business-to-business (B2B) model. (Kumar, 2010)

$\mathrm{B} 2 \mathrm{C}$ model is used by companies which sell their products and services to consumers through Internet. B2C model involves a service or product exchange from a company to a consumer, whereby merchants sell products to consumers. Although the core of the model is e-commerce transactions, it encompasses wide range of marketing activities supporting the transactions. In other words, a business that sells online merchandise to individual consumers is categorized as B2C model. Many experts have argued that online $\mathrm{B} 2 \mathrm{C}$ activities played a critical role in shaping modern Internet. Companies took advantage of this by creating electronic storefronts after discovering they could sell larger volumes of merchandise through B2C models.

B2B model refers to transactions between enterprises, taking place electronically through Internet, internal networks or private networks. Key factors influencing B2B model expansion are: possibility of secure communication through Internet infrastructure, emergence of private and public B2B markets, requirement for collaboration between suppliers and buyers and technology improvement for internal and external organization integration. Key advantages of B2B model are: eliminate use of paper documents and reduce administrative costs, reduce time cycle of business processes, reduce cost of 
searching appropriate products and services, increase employees productivity in buying and/or sale, reduce errors and improve service quality, reduce cost of researching, increase manufacturing flexibility enabling just in time delivery and increase possibility for collaboration.

Very specific form of e-business we can find in public administration and that form is called electronic government (e-government). E-government could be defined as the creation and delivery of government services through ICT which are used to improve transactions between governments and citizens, governments and businesses, as well as between government agencies itself. Primary technology for creation and delivery of these services is Internet. E-government enables simple and efficient interaction between government and citizens (G2C - Government-to-Citizen), government and business organizations (G2B - Government-to-Business) and between state agencies and organs itself ( $\mathrm{G} 2 \mathrm{G}$ - Government-to-Government). According these entities participating in e-government interactions there are three basic models of e-government: G2C, G2B, G2G. (Siau, Yuan, 2009)

\section{Internet technologies supporting e-business}

Today's consumers have a wide variety of commerce choices: traditional businesses, mega discount stores, catalogs or direct market mail, and Internet. As we can see through explanation of various e-business form and models, Internet, taken as a whole, is a powerful medium where consumers browse, research, compare, and then buy online or, after doing their online collection of information, make the purchase at physical stores. Therefore the backbone of e-commerce is the Internet. The Internet is a collection of millions of computers and networks of all sizes. (Guah, Currie. 2006)

Home and business users as well have following alternatives regarding Internet connection: classical modem, DSL (Digital Subscriber Line) technology, cable technology and mobile technology. Internet connection through classical modem is old technology that is largely abandoned by the most users because it does not obtain satisfied bandwidth. New technologies which provide satisfied bandwidth for data communication and web applications execution are DSL, cable and mobile technology. Common name for these technologies is broadband.

Information on Internet is formatted and transmitted in form of web pages where collection of these pages describing some person or organization is known as web site. Home and business users browse through Internet and visit web sites in order to find information and achieve some interactions referring to buying, education, entertainment etc. There are following categories of web sites: information web sites, interactive web sites and transactional web sites. Information web site obtains users with information on a company and its products and services and serves as a information brochureware. Interactive web site besides information gives possibility to users to be in online interaction and communication with the company. Transactional web site supporting selling of products and services includes shopping card, catalog of products, shopping 
calculator and possibility to accept number of credit card for paying purchased products (Zhenhui et al., 2010).

Companies that know consumers' desires and needs very well and integrate into their web site the appropriate means for customer interactions, will succeed. Web technology opens vast new markets for every company and extends a significant degree of power to companies that recognize how to leverage the efficiencies of this new technology.

Finally, web technology can be used for building internal computer networks of companies. In that case, a company develops internal web site that meets information requirements of the company's employees. Therefore, intranet is private network of an organization that uses Internet standard protocols enabling simple communication, collaboration and information access. Whereas that intranet is based on web technology, it is often called corporate web. Intranet is private network in ownership of some organization, while Internet is public network that is not property of any organization and institution. Internet can be accessed by every person who has technical capabilities for access while intranet can be accessed only by persons who have authorization for access. Intranet can be connected to public Internet, but it is not necessary (Molly et al., 2011).

Access to intranet is limited to users inside an organization. On the other side, there is extranet (extended intranet) enabling access to authorized users outside the organization such as suppliers, buyers, business partners etc. Main problem related to extranet is security and protection of data and resources from unauthorized persons who want to access to the network without permission. Presently, many security methods are used for data protection. The well known methods and technologies are firewall and IP (Internet Protocol) tunneling applications allowing that data is accessed only by authorized users. (O’Brien, Marakas, 2011)

\section{E-business from integrative view}

E-business is more effective if a company achieves high level of integration of its resources including technological resources. There are three most important organizational and technological approaches or concepts that enable such integration: Supply Chain Management (SCM), Customer Relationship Management (CRM) and Enterprise Resources Planning (ERP). (Legner, Schemm, 2008)

Supply Chain Management. In order to timely deliver products to customers, enterprises intend to accelerate business processes in supply chain management (SCM). SCM integrates logistical requirements of suppliers, distributors and customers in cohesive process which enables reduction of delivery time and inventory costs. There are many ICT and software solutions supporting integration, optimization and management of supply chains (Steinfield et al., 2011).

SCM is placed in context of unique business process and material and information flow. The flow goes through whole distribution channel and every individual company as a participant in the supply channel is only one shackle in supply chain where 
interorganizational boundaries are blurring. Every logistic process in an enterprise is part of wider and greater process taking place in whole supply chain. Therefore every managerial logistic decision should be suitable to principles of specific management in whole supply chain. (Klein, Rai, 2009)

Every participant in supply chain, from suppliers to retailers, has possibility to manage its own segment of the supply chain by support of ICT. ICT, particularly internet technology, enables connection of all participants in supply chain. ICT makes SCM more efficient by integration of demand planning, forecasting of manufacturing, material procurement, order processing, inventory allocation, order fulfillment, transport services, receiving of goods, invoicing and payment. ICT enables free flow of material, financial and information resources in supply chain. ICT supports SCM in three different segments: purchase side of supply chain, internal part of supply chain and sell side of supply chain (Cohen, Roussel, 2005).

Enterprise Resources Planning. Beside SCM software solutions, many companies use Enterprise Resources Planning (ERP) software for management of internal part of supply chain. Intent of ERP is to integrate all business processes in organization and to use this integration for performance improvement in relations to customers (Subramanian, Peslak, 2010).

First attempt of enterprises to manage their resources and requirements on integral manner was development and use of Material Requirements Planning (MRP) systems. These were computerized systems for improvement of inventory control and manufacturing planning. In second phase, Manufacturing Resource Planning II (MRP II) system is developed. ERP system practically represents extension of MRP II concept with additional functions for finance, distribution, human resources management which are integrated so that can meet overall requirements of networked enterprise. (Bhardwaj, 2013)

ERP is set of software modules enabling an organization to automatize transactions included in the organization business processes. ERP system enables greater data integration, use of available database and consolidation of great number of various incompatible systems. ERP system usually include finance, order tracking, forecasting, sale analysis, local and global distribution and quality control. ERP systems have powerful tools for monitoring and reporting, but they are quite rigid and their use requires well defined data.

Customer relationship management. CRM is technological and organizational concept for managing a company's interactions with existing and future customers. In order to organize, automate, synchronize and integrate sales, marketing, customer service, and technical support the company can use various technologies where the most significant is web technology. The company should have software and usually Internet capabilities that support management of customer relationships in an organized way. For example, the company can develop a database about its customers. The database is used by management, salespeople, people providing service and customers. 
Relationships with customers in the database should be well described so these users could directly access information, match customer needs with product offerings, remind customers of service requirements, know what other products a customer had purchased, and so forth.

Therefore these capabilities of CRM allow the users to: analyze information about customers taken from one or multiple systems operating online; understand customer needs, differentiating between customers via market segmentation; predict the likelihood of customer loyalty, and profitability through rigorous analysis; evaluate channel effectiveness, campaign performance, sales results, and other critical factors (Shanks et al., 2009).

The synergy between ERP, CRM, and SCM is evident if we put the entire issue into perspective. CRM deals with more issues in the front-end processes and applications than ERP. ERP, to a considerable extent, targets back-end processes and applications, and provides a central focus for the entire business that is integrated with the internetoriented supply chain. Also we must take into account new technical requirements expected in the near future such as mobile access to ERP systems and use of cloud technology to create environment for ERP, CRM, and SCM. (Demirkan et al., 2010)

\section{Research of Internet use and potential of e-business in Serbia}

Using opportunities and potentials of e-business depends on level of acceptance and application of Internet. This is why we need empirical investigations presenting the level of Internet acceptance and application by individual consumers and organizations in Serbia. The level of Internet acceptance of individual consumers is significant for estimation of B2C e-business while the level of Internet acceptance and use in organizations is significant for analysis and forecasting of B2B e-business potential. In addition, if a modern organization tries to have clear view to potential of B2B e-business, it needs data on current and forecasted level of Internet acceptance and use by its buyers and suppliers

\section{Materials and methods}

As we mentioned previously, information considering application of Internet and e-business in Serbia is collected by Statistical Office of the Republic of Serbia on the sample of 2400 households and 1400 enterprises in 2013 (SORS, 2013). The author of the paper is only using it for making analysis and conclusions and try to give brief review of some interesting and most important information relating to Internet use and e-business concept acceptance on individual and organizational level in Serbia.

Research of households and individuals made by telephone interview is conducted from 17. to 31. march in 2014. Target population for households is all households with at least one member with age between 16 and 74. Target population on individual level is all the people with age between 16 and 74. Type of this sample is two-phased and stratified. Scope of this research is territory of Republic of Serbia without the 
Autonomous Province of Kosovo. Individuals are divided by gender, level of education, level of households' income and employment or unemployment status.

From this comprehensive interview we derive some interesting questions important for our research:

- Do you and any other person from your household have Internet access from home no matter that is used or not?

- When did you use Internet last time?

- Which activities did you achieve through Internet for private purpose in last three months?

- Which type of goods and services did you buy or order through Internet in last 12 months?

On the other side, the research of enterprises made by telephone interview is conducted from 17. to 30. April in 2014. Target sample was 1200 enterprises with 10 and more employees from following industries: manufacturing production; supply of electric power, gas and water; construction; wholesale and retail; traffic, transport and warehousing; hospitality industry services; information and communication, real estate industry and scientific and technical sector; administrative services and computer repair; banking and insurance industry.

Also this sample is stratified and representative and it encompasses territory of Republic of Serbia without the Autonomous Province of Kosovo. Response rate on this telephone interview was 92,7\% (1112 enterprises).

From this interview regarding our enterprises we derive some interesting questions important for our research:

- Does your enterprise have Internet connection?

- Does your enterprise use DSL or the other broadband Internet connection?

- Does your enterprise have web site?

- Did your enterprise use services of public administration by Internet during 2013?

- Does your enterprise exchange information regularly and electronically in supply orders management with its suppliers and customers?

- Did your enterprise receive orders or deliver services through web site (except e-mail orders) during 2013?

- Did your enterprise order products and services through web site or EDI technology during 2013?

\section{Analysis of results}

This section of the paper presents responses to mentioned questions from interview and analyses data considering Internet use by individuals and enterprises for purpose of e-business. Although this analysis seems superficial it can give some useful insight to potentials of e-business in Serbia.

Some relevant facts on Internet use considering households are that $62.8 \%$ of households in Serbia have Internet connection in 2014 (increasing for $7 \%$ in comparison with 
2014), and $55.1 \%$ of households with Internet connection have broadband Internet. If we view to type of used broadband technology, we can see that DSL technology is used by $54.6 \%$ of households, cable Internet is used by $35.3 \%$ households and mobile $3 \mathrm{G}$ network is used by $24.1 \%$. Relevant fact for mobile commerce is that $90.6 \%$ of Serbian citizens use mobile phones, and it is great potential for m-commerce development that is not fully used in Serbia.

If we compare Serbia with countries of European Union, we can conclude that relatively small number of households have Internet connection. This is shown on figure 1 where the graphic presents relative position of Serbia when we consider percentage of households in Serbia with Internet connection. Interesting fact is that the other Balkan countries (Greece, Bulgaria and Romania) which are EU members also have low position on the graph in comparison to the other EU members.

Figure 1. Percentage of households with Internet connection in EU and Serbia

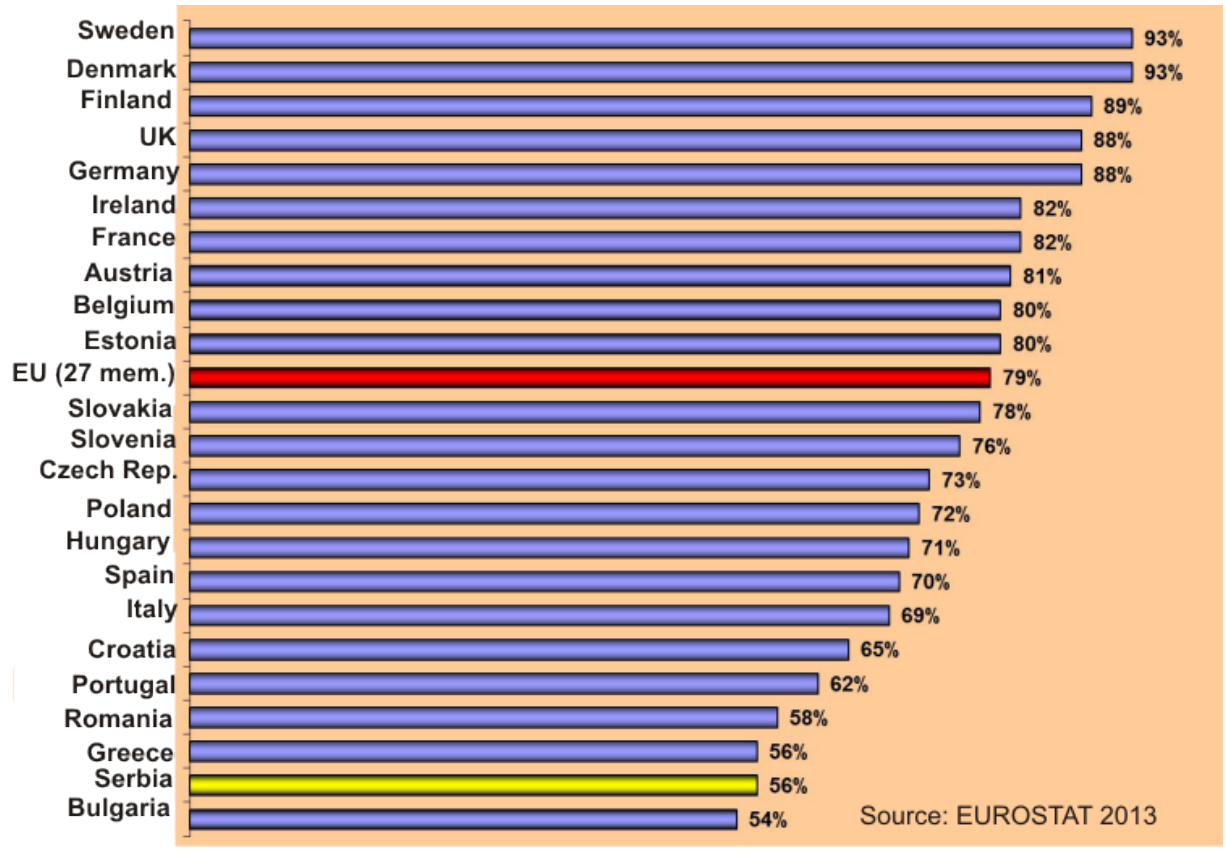

Source: SORS (Statistical Office of the Republic of Serbia), 2014.

When we consider Internet use in Serbia on individual level, collected data shows that $62.1 \%$ of interviewed individuals used Internet in last three months, $1.9 \%$ of interviewed individuals used Internet before more than 3 months and 2.9\% used Internet before more than one year. Even $33.1 \%$ of interviewed individuals never used Internet that is very high level if we start with premise that we live in Internet era. Nevertheless number of Internet users was increased for 8.4\% in comparison with 2013.

Relevant information for development and potential of e-business in Serbia is purpose of Internet use. From that point of view, 37.4\% of interviewed Internet users use services 
of electronic government. Collected data shows that $36 \%$ of interviewed Internet users use Internet tools for getting information from web sites of public institutions or public administration organs, $20.6 \%$ of interviewed Internet users download official forms from the web sites and $13.1 \%$ of interviewed Internet users send filled forms. Purpose of Internet use in Serbia according to collected information is also presented in figure 2.

Figure 2. Purpose of Internet use in Serbia

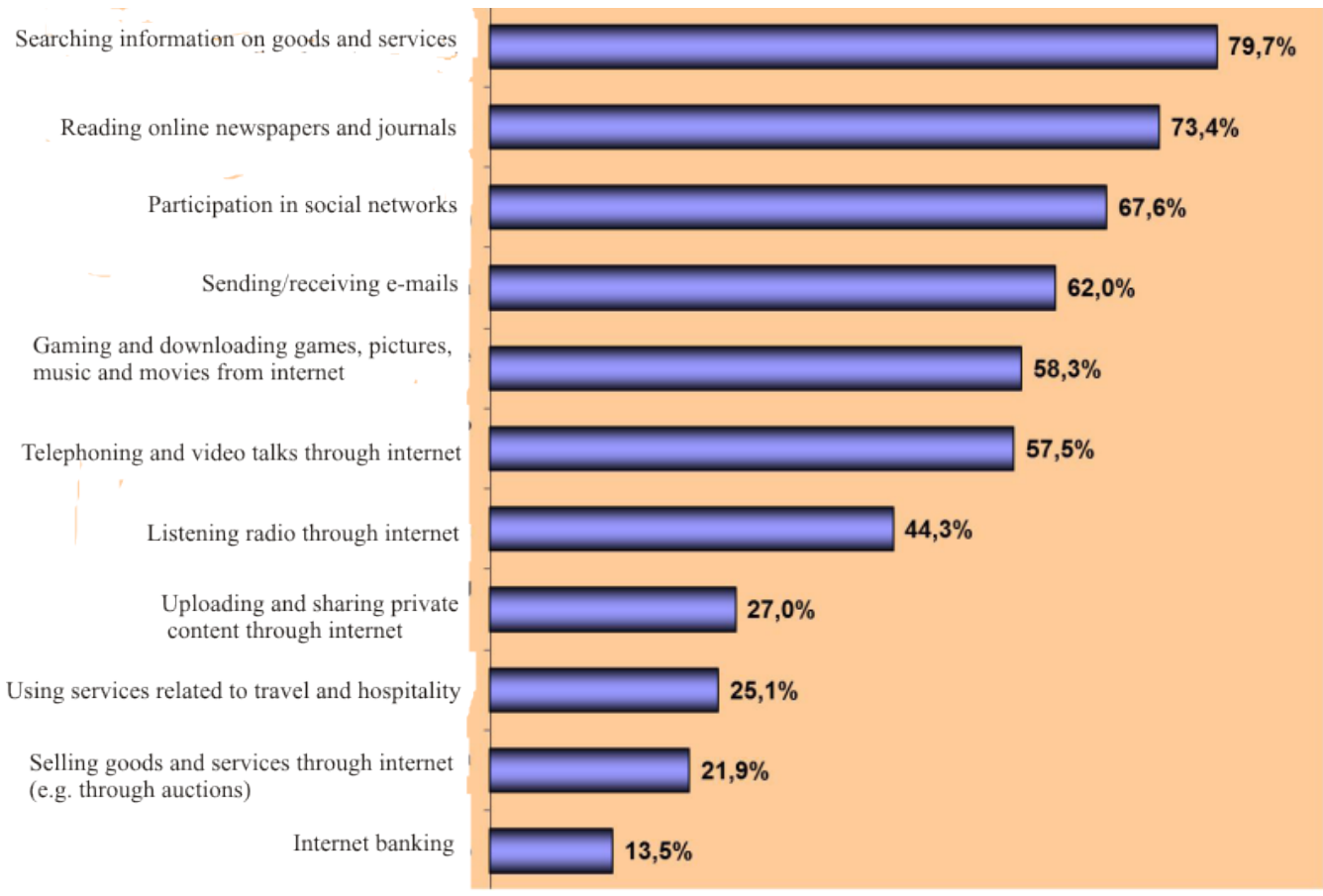

Source: SORS, 2014.

Considering online buying or ordering goods and services $21.6 \%$ of Internet users in Serbia bought/ordered products and services online in last three months, $10.2 \%$ of users bought online before more than three months, and $8.8 \%$ before more than one year. Very high percent $(59.5 \%)$ of Internet users in Serbia never used Internet for buying and ordering products and services. Figure 3 presents products and services that are most frequently bought and ordered through Internet.

If we compare Serbia with countries of European Union, we can conclude that relatively small number of people used Internet in last three months. This is shown on figure 4 where relative position of Serbia is very low in comparison with EU countries.

Data on Internet use on enterprise level can be used for analysis and making conclusions mainly about B2B e-commerce as well as about B2C e-commerce. So we present some basic facts on Internet implementation and internet technologies used in e-business of Serbian enterprises. Therefore, some relevant facts on Internet use in the enterprises 
show that $100 \%$ of examined enterprises in Serbia have Internet connection and $74 \%$ of enterprises with Internet connection have web sites. Considering type of Internet connection, broadband technology is prevalent: $98 \%$ of examined enterprises use this kind of connection.

We may say that high percentage of enterprises in Serbia with Internet connection have web sites, but we can see right picture of web site implementation if we consider services offered by these sites. Namely, prevalent services $(83 \%)$ offered by these sites are dedicated to presenting static content adjusted to regular visitors of the sites. Only $21 \%$ of services enable online ordering of products/services and $11 \%$ of services enable online payment. Conclusion from these facts is that great number of these web sites do not support the most important online buying activities.

Figure 3. Products and services that are most frequently bought and ordered through Internet

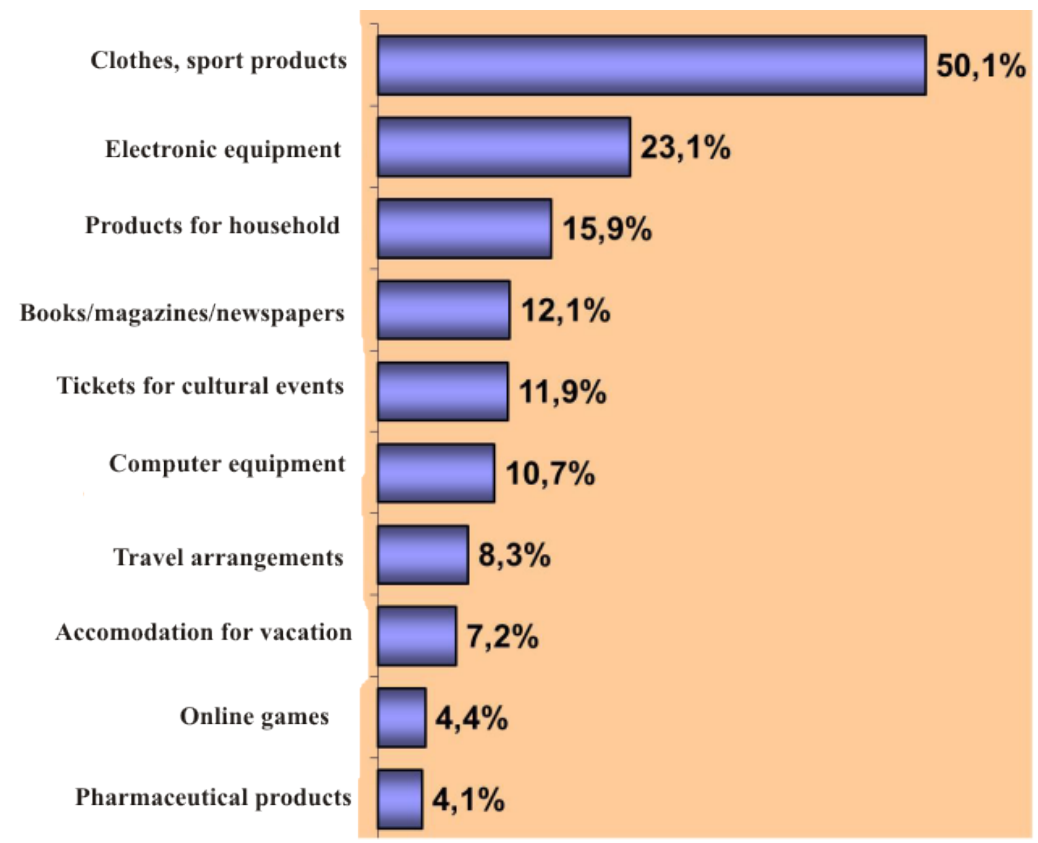

Source: SORS, 2014.

Finally, some relevant facts on e-business of Serbian enterprises shows that $88 \%$ of examined enterprises with Internet connection use services of electronic government, $40.4 \%$ of enterprises with Internet connection ordered products/services via Internet during 2013 and $21.2 \%$ of enterprises with Internet connection was receiving online orders during 2012 (orders by email are not included). Conclusion that can be derived from these facts is that Internet is more used for e-procurement than for online selling, but overall development level of enterprises' e-business in Serbia is very low. 
Figure 4. Percentage of people who used Internet in last three months

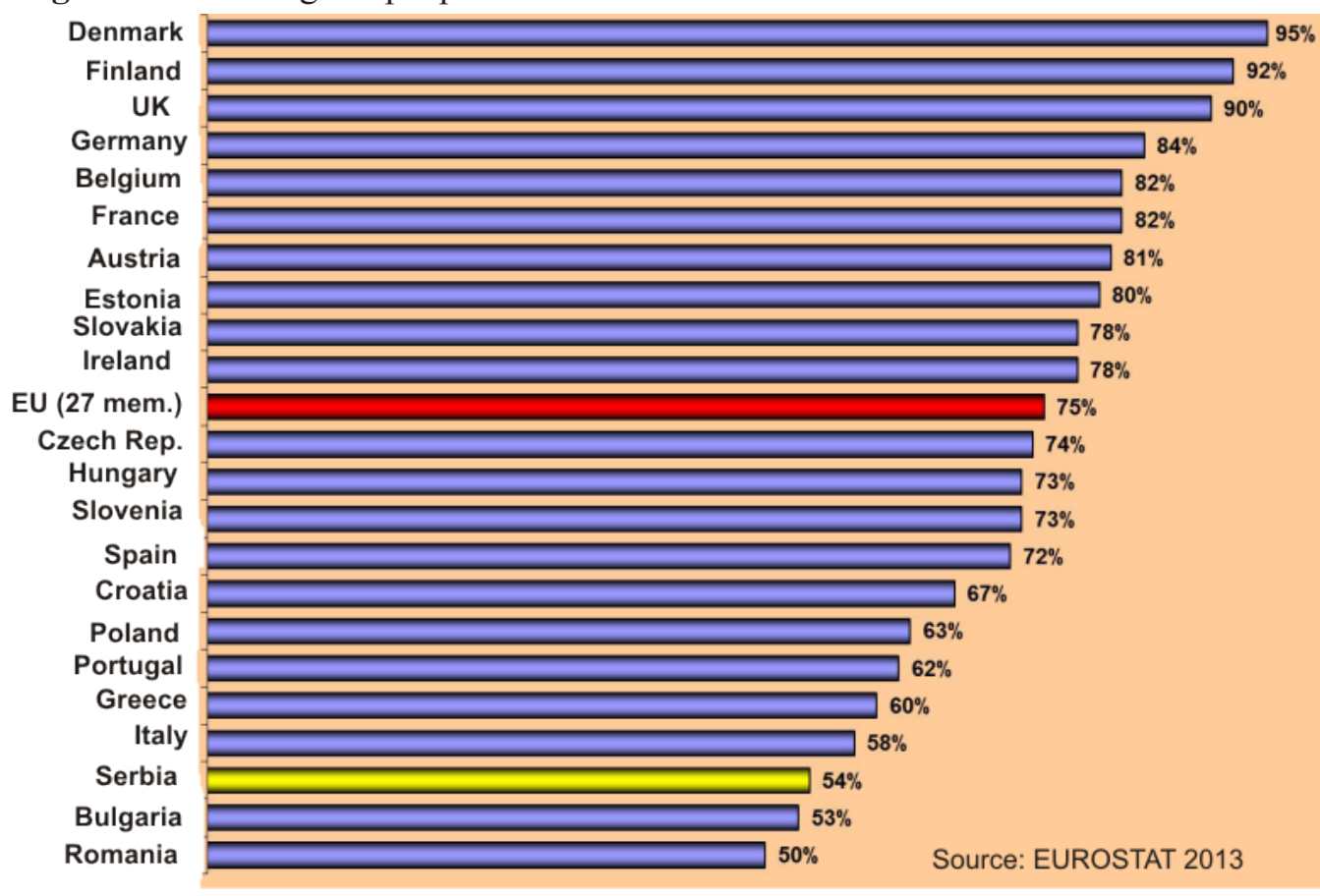

Source: SORS, 2014.

\section{Discussion of results}

The results of research presented in the paper undoubtedly shows that there are good technical potentials for implementation of e-business concept in Serbia, because almost all organizations have Internet connection and use internet technology. However, potentials of internet technology are not used enough for building web sites and implementation of e-business concept considering B2C and B2B model of e-commerce as well ( $74 \%$ of enterprises with Internet connection have web sites). This is also shown by data about services that enterprises deliver through the web sites because visitors of the sites mainly collect information on products and services but very seldom buy and pay through Internet (only $21 \%$ of web sites enable online ordering of products/services and $11 \%$ of the sites enable online payment). The web sites are more used as electronic brochureware than for accomplishment of selling transactions. Not only that electronic selling is very small but internet technology is used for electronic procurement to relatively small extent. That is presented by small percent of enterprises $(40,4 \%)$ which oredered products and services through Internet. However, encouraging fact is that number of enterprises which are ordered products/services via Internet is increased almost by $50 \%$ in comparison to 2012 .

Technologies enabling integration of e-business are used to very low extent in our enterprises, because $9.9 \%$ of all examined enterprises used ERP technology, and 14\% 
of enterprises used CRM technology. Applications of e-business are fragmented and encompasses some activities in business functions, but they are not connected and logically integrated.

Percent of households in Serbia having Internet connection is very small in comparison with developed European countries. Situation is similar when we take into account percent of indiviuals who used Internet in last three month of examined period. According to all these parameters, Serbia is on the bottom of the list of European countries. However fact of increasing number of Internet users in Serbia is encouraging.

The results of research show that level of development of e-business in Serbia is relatively low. This level is low because fact that our Internet users visit web sites for searching entertainment and social relations but buying goods and services is not usual activity of our Internet users. However trend of Internet expanding in Serbia shows that we may expect increasing number of Internet users and increasing number of potential Internet buyers that will be incentive for development of $\mathrm{B} 2 \mathrm{C}$ electronic commerce.

Information from this research can help managers in our enterprises when they plan implementation or expending e-business. The information shows present state and potentials for e-business implementation as well. For example, products and services which are mainly ordered by Internet shows present demand of users for e-shopping. We can expect that demand for these products and services will keep in the future so it is potential for development of e-business in industries that produce these products. However if buyers have not interest for products of an enterprise, managers of the enterprise should think of Internet campaigns by which actuat this interest.

Except managers in organizations, results of this research can be used by researchers for deeper analysis of specific themes which are opened and searching answers on questions derived from presented data. One of the most important question is, which are the reasons for inappropriate implementation of ICT in e-business concept of realization. Future researches will also encompass organizations and populations. Opinion of managers about reasons for poor acceptance of e-business concept would be examined in organizations. The same reasons would be examined in the case of citizens as individual users of Internet. Very important questions are: Why users of Internet do not use this communication channel in greater extent for buying of goods and services? Why organizations which have Internet connection did not build web site for selling its products and services? Do the organizations plan to do it and in which period of time? Why organizations do not use Internet for procurement of materials in more extent?

Finally, policy makers in Serbia may identify problems in the future development of ICT infrastructure, on the base of the research. The greatest problem is how to make Internet infrastructure accessible to more number of people and organizations by acceptable prices and how to decrease inequality between regions, social groups and the other categories of population considering ability to use Internet. Some measures for development and improvement of ICT infrastructure which are in responsibility of public administration are undertaken. For example, measures for deregulation of 
telecommunication services market are undertaken. Deregulation, free market and strong competition in this area contribute to improvement of the services offering by acceptable prices. The best example for that is market of mobile communication services so to that direction should plan future polices.

\section{Conclusion}

In conclusion we may say that level of Internet use and adoption of e-business concept is very low in Serbia, when we compare our country with EU countries. However, potential for Internet expansion in Serbia is very high in comparison with developed countries of EU. For example, in Denmark, $93 \%$ of households have Internet connection, and potential for expansion is very limited. Potential for development of all e-business models, particularly B2C e-commerce is also high. For example, 59.5\% of Internet users in Serbia never used Internet for buying and ordering products. They are potential online shoppers, but they should be encouraged to buy online. Idea for future research is just to examine why Serbian Internet users do not buy online. When we find factors influencing readiness for online shopping we can act on these factors.

\section{Literature}

1. Bhardwaj, A. (2013): Transforming business: Integrating ERP with E-business, International Journal of Advanced Research in Computer Scinece and Software Engineering, vol. 3, no. 7, pp. 653-656. IJARCCE, India.

2. Cohen, S., Roussel, J. (2005): Strategic supply chain management: The five disciplines for top performance. McGraw-Hill Companies, Inc., New York, United States of America (USA)

3. Demirkan, H., Cheng, H. K., Bandyopadhyay, S. (2010): Coordination strategies in an SaaS supply chain, Journal of Management Information Systems, vol. 26, no. 4, pp. 119-143. Taylor \& Francis Group, Abingdon, United Kingdom (UK).

4. Guah, M. W., Currie, W. L. (2006): Internet strategy: The road to web services solutions, Idea Group Inc., Hershey, USA.

5. Ivković, M., Radenković, B. (1998): Internet i savremeno poslovanje: Osnovni koncepti poslovanja na Internetu, Tehnicki fakultet M. Pupin, Zrenjanin, Srbija.

6. Jovanović, R., Milovanović, S. (2010): Elektronsko poslovanje, Ekonomski fakultet u Nišu, Niš, Srbija.

7. Klein, R., Rai, A. (2009): Interfirm strategic information flows in logistics supply chain Relationships, MIS Quarterly, vol. 33, no. 4, pp. 735-762. Carlson School of Management, University of Minnesota, Minneapolis, USA

8. Končar, J. (2003): Elektronska trgovina, Ekonomski fakultet u Subotici, Subotica, Srbija.

9. Kumar, P. (2010): Integration of E-business with ERP systems, International Journal of Engineering Scinence and Technology, vol. 2, no. 5, pp. 768-772. Elsevier B.V., 
Amsterdam, The Netherlands

10. Legner, C., Schemm, J. (2008): Toward the Inter-organizational Product Information Supply Chain - Evidence from the Retail and Consumer Goods Industries, Journal of the Association for Information Systems, vol. 9, no. 4, pp. 119-150. Association for Information Systems, Atlanta,USA.

11. O’Brien, J. A., Marakas, G. M. (2011): Management information systems, McGrawHill, New York, USA.

12. Radenković, B., (2007): Elektronsko poslovanje - stanje i perspektive. FON, Beograd, Srbija.

13. Shanks, G. Jagielska, I., Malini, J. (2009): A framework for understanding customer relationship management systems benefits, Communications of AIS, vol. 2009, no. 25, pp. 263-287. Association for Information Systems, Atlanta, USA.

14. Siau, K., Long, Y. (2009): Factors impacting e-government development, Journal of Computer Information Systems, vol. 50, no. 1, pp. 98-107. Taylor \& Francis Group, Abingdon, UK.

15. SORS (Statistical Office of the Republic of Serbia) (2014): Use of information and communication technologies in Republic of Serbia, Available at: http://webrzs.stat. gov.rs/WebSite/repository/documents/00/01/50/47/PREZIKT2014.pdf. SORS, Belgrade, Serbia

16. Steinfield, C. Markus, M. L., Rolf, T. W. (2011): Through a glass clearly: Standards, architecture, and process transparency in global supply chains, Journal of Management Information Systems, vol. 28, no. 2, pp. 75-108. Taylor \& Francis Group, Abingdon, UK.

17. Subramanian, G., Peslak, A.R. (2010): User perception differences in enterprise resource planning implementations, Journal of Computer Information Systems, Vol. 50, No. 3, pp. 130-138. Taylor \& Francis Group, Abingdon, UK.

18. Wasko, M. Teigland, R., Leidner, D., Sirkka, J. (2011): Stepping into the Internet: New ventures in virtual worlds, MIS Quarterly, vol. 35, no. 3, pp. 645-652. Carlson School of Management, University of Minnesota, Minneapolis, USA.

19. Yoo, B. Choudhary, V., Tridas, M. (2011): A study of sourcing channels for electronic business transactions, Journal of Management Information Systems, vol. 28, no. 2, pp. 145-170. Taylor \& Francis Group, Abingdon, UK.

20. Zhenhui, J., Chan, J., Tan, B. C. Y., Chua Wei Siong (2010): Effects of interactivity on website involvement and purchase intention, Journal of the Association for Information Systems, vol. 11, no. 1, pp. 34-59. Association for Information Systems, Atlanta, USA. 


\title{
MOGUĆNOSTI RAZVOJA ELEKTRONSKOG POSLOVANJA U SRBIJI
}

\section{Slavoljub Milovanovic ${ }^{2}$}

\begin{abstract}
Rezime
Intenzivno korišcenje informacionih i komunikacionih tehnologija (IKT), naročito interneta, u poslovnim procesima prodaje i kupovine je prouzrokovalo razvoj koncepta elektronskog poslovanja (e-poslovanja). Brojne organizacije u svetu, kao i u Srbiji, su implementirale ovaj koncept. Osnovni cilj ovog radaje da analizira nivo implementacije internet tehnologije i e-poslovanja u Srbiji. Ovaj rad ima teorijsku pozadinu koja objašnjava koncept e-poslovanja i IKT koje podržavaju implementaciju ovog koncepta. Medjutim, empirijski ili praktični doprinos ovog rada je izražen kroz analizu podataka koji se odnose na primenu IKT i koncepta e-poslovanja u Srbiji. Ove podatke je prikupio Republički zavod za statistiku Srbije, a obuhvataju domaćinstva/pojedince i preduzeća u Srbiji. Rezultati istraživanja prezentirani u ovom radu mogu pomoći rukovodiocima u srpskim organizacijama u planiranju implementacije koncepta e-poslovanja, kao $i$ istraživačima u dubljem proučavanju ove teme.
\end{abstract}

Ključne reči: Elektronsko poslovanje, elektronska trgovina, Internet, Srbija

2 Profesor, dr Slavoljub Milovanović, Univerzitet u Nišu, Ekonomski fakultet, Trg Kralja Aleksandra br. 11, 18000 Niš, Telefon: +381 18528 644, E-mail: smilovan@eknfak.ni.ac.rs 